\title{
Effects of Bivalve Aquaculture on the Environment and Their Possible Mitigation: A Review
}

Daria Gallardi*

Fisheries and Oceans Canada, 80 East White Hills Road, PO Box 5667, St John's, NL, A1C 5X1 Canada

\begin{abstract}
Bivalve aquaculture, in particular oyster, clam, scallop and mussel culture, is a globally increasing activity. Increased bivalve production translates inevitably into increased impact on the environment surrounding the aquaculture activities. The effects of this type of aquaculture on the environment are often considered less important compared to those of finfish culture. However, bivalves due to their natural characteristics are considered keystone species in the ecosystem and therefore they have the ability to affect the surrounding environment in both negative and positive ways. They influence primary and secondary productivity and start a series of cascade effects on water column and sediment population and dynamics. The purpose of this article is to present a review of the effects of bivalve aquaculture on the surrounding environment and the current mitigation strategies. In addition, this review highlights how the same natural characteristics of bivalves can positively interact with the environment, and the possible use of bivalve aquaculture as restoration and remediation tool for marine environments.
\end{abstract}

Keywords: Bivalve; Aquaculture; Environment interactions; Benthic habitat; Positive effects; Sustainability

\section{Introduction}

Global bivalve aquaculture production has been increasing constantly over the past 20 years. The main bivalve species cultured in the world are oyster, clam, scallop and mussel [1]. Bivalve aquaculture is considered to have less dramatic environmental impact compared to finfish culture, since it requires minimal addition to the environment. For the main species cultured the food is supplied by the environment itself and the wastes return nutrients and minerals to the ecosystem [2]. However, bivalves have the ability to maintain, modify and create entire habitats due to their effects on suspended particles and their shell formations $[2,3]$. The majority of research on interaction between bivalve culture and the environment has been concentrated on mussel and oyster, probably because the production of other bivalves such as clams and scallops is greater in Asia, where aquaculture and its effects have been a culturally accepted part of the coastal environment for centuries [4].

The purpose of this article is to present a review of the effects of bivalve aquaculture on the surrounding environment, particularly in estuarine and coastal zones, the current prevention and mitigation strategies and highlight how bivalve culture can positively interact with the environment.

Bivalves are suspension feeders that perform their functions in a range of habitats, in particular estuaries, lagoons and coastal oceanic systems. They gain nourishment by filtering suspended particles such as phytoplankton and detritus from the water column [3]; it has been calculated that an oyster can filter on average 15 to 55 liter/day of seawater [5,6]. Bivalve by-products are dissolved ammonium and bio-deposits of feces and pseudofeces; they sequester nitrogen in the form of protein in meat and shell and stabilize phytoplankton growth dynamics through the moderation of ammonia cycling in the water column. They are therefore considered "keystone" species which exert "top-down" control of phytoplankton by grazing but also "bottom-up" control through biodeposition and promotion of nutrient removal [3,6-9]. Epifaunal bivalves such as oysters and mussels respond to increased levels of phytoplankton and detritus in the water column with increased filtration capacity and production of pseudofeces.
Infaunal bivalves such as clams adjust their clearance rates rather than increasing production of pseudofeces $[9,10]$. These processes affect the food web, the biogeochemical cycling, and the physical and chemical environment, potentially modifying habitats and ecological functioning $[3,9]$.

Bivalve aquaculture has therefore the ability to affect the environment in both negative and positive ways, with a variety of near and far field cascading effects on different parts of the ecosystem, including influencing primary and secondary productivity and community structure. Culture structures and operations can alter water flows, sediment composition and sedimentation rate, and disturb the benthic flora and other marine organisms $[4,9,11,12]$.

Estuaries are often a preferred site for bivalve culture and therefore are the environments examined by the majority of literature. The species that can exert the highest influence on the environment are oysters and mussels, since they maintain high clearance rates and reject large numbers of particles as pseudofeces $[2,8]$. The direct comparison of impact between clam (Tapes philippinarum) and mussel (Mytilus galloprovincialis) culture located in the same body of water has in fact shown a greater impact for mussel culture [13].

There is more than one way a system can react to bivalve culture:

- The bivalve can redirect energy away from the zooplankton, replacing its ecological role and grazing on phytoplankton, leading to less energy passing up to the higher pelagic trophic level.

- Bivalves can direct energy away from benthic filter-feeders,

*Corresponding author: Daria Gallardi, Fisheries and Oceans Canada, 80 East White Hills Road, PO Box 5667, St John's, NL, A1C 5X1, Canada, Tel: +709749 0578; Fax: +709 772 7176; E-mail: daria.gallardi@dfo-mpo.gc.ca

Received May 30, 2014; Accepted August 28, 2014; Published September 05 2014

Citation: Gallardi D (2014) Effects of Bivalve Aquaculture on the Environment and Their Possible Mitigation: A Review. Fish Aquac J 5: 105. doi: 10.4172/21503508.1000105

Copyright: $\odot 2014$ Gallardi D. This is an open-access article distributed under the terms of the Creative Commons Attribution License, which permits unrestricted use, distribution, and reproduction in any medium, provided the original author and source are credited. 
decreasing their population and opening an ecological niche for benthic deposit feeders.

- $\quad$ Finally, bivalves can redirect energy from the bacteria in the microbial loop by recycling particulate nitrogen to inorganic nitrogen resulting in a noticeable increase in rates of primary productivity and less detritus.

It is however likely that these three processes can occur concurrently [14]. Based on Gavine \& Mc Kinnon's [15] hazard assessment for oyster (Pacific, Sydney rock and pearl) and blue mussel (Mytilus edulis) culture in Australia, the higher risk of impact was associated with the deterioration of sediment quality, the alteration of sediment physical structure and the impact on seagrass beds.

The effects of bivalve aquaculture on the environment have been classified in different ways throughout the literature. For the purpose of this manuscript they will be divided in four main effects: on the water column, on the sediment, effects of bivalve introduction and effects on other marine species (including marine mammals and birds). A summary of these effects is reported in Table 1.

\section{Ecological Effects of Bivalve Aquaculture}

\section{Effects on water column and nutrients}

Bivalves affect the water column through filtration and grazing, and through modification of the nutrient cycle, with direct excretion and microbially mediated remineralisation of their organic deposits in sediments $[9,10]$. Large bivalve assemblages have the ability to modify phytoplankton populations and blooms. They can regulate the abundance of phytoplankton in shallow seas and reduce phytoplankton bloom intensity. Reduced turbidity due to bivalve grazing can increase light, a limiting factor for the growth of other species, such as algae $[2,8,10,16,17]$. Grazing reinforces seasonal successional cycles in phytoplankton composition. Picoplankton is favored by warmer waters and by changes in relative abundance of organic and inorganic nitrogen and it is also retained less efficiently on the gills of bivalves, while nanoplankton is preferentially removed by grazing. Therefore, during warmer seasons, with the help of bivalves, picoplankton becomes relatively more abundant than larger species $[8,18,19]$.
The effects of bivalves on nutrient cycling include marked changes in the nitrogen distribution, especially contribution of nitrogen in the form of ammonium $\left(\mathrm{NH}_{4}^{+}\right)$, removal of phosphorus through biodeposition and recycling of silicate through transfer from water column to the sediment. The ammonium excreted by bivalves is immediately available for primary production; therefore bivalves have a positive effect on primary production by increasing the nitrogen turnover in the water column. Bivalves such as mussels may also concentrate certain metals like copper in their pseudofeces $[2,3,16]$. The extent to which the overall nutrient budget and primary production are affected by bivalves is related to their abundance, location, system flushing rate and residence time. Therefore, a population of cultured bivalves has the potential to modify the nutrient cycle in coastal ecosystems in that carbon and nitrogen ingested as phytoplankton are converted into other forms and concentrated near the culture area. It has been postulated that changes in relative concentration of silica, nitrogen and phosphorus could facilitate growth of harmful phytoplankton classes. For instance, promotion of algal blooms of Pseudo-nitzschia in relation to eutrophication has been demonstrated, though a direct link between these blooms and bivalve culture sites is still speculation. In the end bivalve aquaculture is a net remover of nutrients from the ecosystem through harvesting of the product $[2,3,9,15,16,18]$.

\section{Effects on sediments and benthic habitat}

Bivalve filter-feeders effectively remove natural suspended matter with a diameter between 1 to $7 \mu \mathrm{m}$, depending on species, and return large fecal pellets of $500-3000 \mu \mathrm{m}$. This pellet rapidly settles to the seabed, particularly when slow or poor water flushing and exchange conditions exist. This particle repacking diverts primary production and energy from planktonic to benthic food webs $[2,3]$. The bulk of research regarding bivalve aquaculture and sediment focuses on the effects of increased organic load to the sediments from biodeposition, habitat modification associated with culture gear and consequent changes in local fauna $[9,10]$.

In the sediment, the rate of accumulation or dispersion of biodeposits and the severity of impact created by bivalves depends on water depth and prevailing currents close to the seafloor. In the literature, a variety of observations on cultured bivalve biodeposition have been reported,

\begin{tabular}{|c|c|c|}
\hline & Effect & Consequences \\
\hline \multirow{4}{*}{ Water column and nutrients } & Phytoplankton modification & Bloom modification \\
\hline & Reduced turbidity & Increased light penetration \\
\hline & Increased NH4+ & Increased primary production \\
\hline & Metals concentration & \\
\hline \multirow{7}{*}{ Sediment and benthic habitat } & \multirow{4}{*}{ Increased deposition } & Anaerobic sediment \\
\hline & & Increased bacteria and meiofauna \\
\hline & & Decreased suspension-feeders \\
\hline & & Increased deposit feeders \\
\hline & Modification of topography and hydrography & Habitat creation/modification \\
\hline & \multirow{2}{*}{ Removal of calcium carbonate } & Increased acidification \\
\hline & & Decreased positive feed-back \\
\hline \multirow{5}{*}{ Other marine species } & \multirow{4}{*}{ Nutrient and habitat modification } & Increased crustaceans \& some fish \\
\hline & & Seagrass displacement \\
\hline & & Disturbance for mammals and birds \\
\hline & & Creation of new habitat for birds \\
\hline & Food competition & Decreased zooplankton \& larval fish \\
\hline \multirow{2}{*}{ Introduction } & \multirow{2}{*}{ Introduction of nonnative species } & Diseases introduction \\
\hline & & Pest introduction \\
\hline
\end{tabular}

Table 1: Main effects of bivalve aquaculture on the environment and their direct consequences. Grey highlight represents effects that can be considered both negative and positive depending on the situation. 


\begin{tabular}{|c|c|c|}
\hline Effect & Evaluation measure & Prevention \\
\hline Phytoplankton modification & Environmental indicators (water) & Ecological carrying capacity models \\
\hline Nutrient modification & Environmental indicators (water) & Ecological carrying capacity models \\
\hline Increased deposition & Environmental indicators (sediment) & Ecological carrying capacity models \\
\hline Benthic fauna modification & Environmental indicators (sediment) & Ecological carrying capacity models \\
\hline Habitat modification & Environmental indicators (sediment) & Ecological carrying capacity models \\
\hline $\begin{array}{c}\text { Effects on marine mammals and birds } \\
\text { bivalve aquaculture }\end{array}$ & $\begin{array}{c}\text { Environmental risk assessment BMP \& } \\
\text { codes of conduct }\end{array}$ \\
\hline $\begin{array}{c}\text { Introduction of nonnative species, } \\
\text { diseases and pests }\end{array}$ & Quarantine Hatchery Testing & $\begin{array}{c}\text { Environmental risk assessment BMP \& } \\
\text { codes of conduct Legislation }\end{array}$ \\
\hline
\end{tabular}

Table 2: Evaluation measures and prevention methods for the main effects of bivalve aquaculture on the environment. Evaluation and prevention measures may be employed separately or in conjunction under an ecosystem-based management plan.

including little or negligible impact, low sedimentation rates and absence of major changes in benthic infauna [20-22]. In other cases the benthic community presented strong long-term effects. For example it has been shown that adult mussels (Mytilus edulis) are able to increase natural sedimentation rates by an average factor of 26 [2]. Kaspar [16] noted consistently higher nitrogen pools in sediments under a mussel farm, suggesting accumulation of inorganic nitrogen. When the organic biodeposition reaches high levels, its decomposition can increase oxygen demand and generate an anaerobic environment that promotes ammonification, sulfate reduction and silicate flux increase $[2,3,8,10,18,23]$. Benthic responses to organic enrichment include an increase in bacterial abundance, meiofauna community and biomass, and reduction in macrobenthic infaunal abundance and diversity $[2,16,20,23]$. Bivalves have the capability to transform a diverse benthic community dominated by suspension feeders (bivalves, crustaceans and some polychaetes) into one dominated by smaller opportunistic deposit feeders, such as polychaetes, scavengers, carnivores and hydrogen sulphide-tolerant species [12,16,19,23-26].

Despite the variety of impact severity found in literature, there is however a consensus on the fact that aquaculture activities in intertidal high energy well flushed areas generally results in dispersal of the organic biodeposits with a lesser impact on sediments. On the other hand, culture in sub-tidal quiescent low energy areas can potentially produce a large accumulation of biodeposits and therefore have a greater localized impact on the benthos $[8,9,15,19-21,24,26]$. In addition to the physical and hydrodynamic characteristics of the site, the scale of the operation and the technique used will determine the impact of bivalve culture on sediments and benthic populations. For instance, activities such as mussel harvesting by bottom dredging practiced in Germany, Netherlands, Irish Sea and Maine results in greater impacts on benthic habitat [9].

It is important to mention the processes related to bivalve shell formation, which capture carbon in the form of calcium carbonate. After natural mortality of the bivalve, the carbon can be sequestrated in the surface sediment, where it provides local buffering against ocean acidification. Moreover, there is a positive feedback process between bivalves and carbonate addition to the sediment: the bivalve carbonate producers provide a critical sedimentary constituent promoting the long-term survival of their own species [9]. However, with current aquaculture practices the source of carbonate is extracted from the marine system and discarded on land. This practice coupled with ocean acidification can accelerate carbonate loss in estuarine and coastal systems and diminish the positive feedback and the provision of habitat that support recruitment, growth and survival of the bivalves themselves [9]. Bivalve shells also have the potential to change seabed topography and hydrodynamic conditions and therefore provide novel habitats which would normally not occur in a certain environment $[10,18,25,26]$. It has been indicated that a mussel farm situated in a sheltered site can add up to $10 \mathrm{~cm} /$ year of biodeposit largely constituted by shells, resulting in changes to the seabed up to $20 \mathrm{~m}$ from the farm boundaries [24,26]. The material accumulation can provide sites of attachment for large epibiota, such as tunicates, sponges and calcareous polychaete [16]. Oyster is an important species to consider when discussing shell deposition since oyster reefs are known to provide a habitat that can support a diversity of taxa. When oyster culture is located on soft- sediment habitats, dominated by flat sand or mud, its impact could result in fundamental long-term shifts in benthic community composition $[3,10,25]$. It has been observed that both oyster and mussel introduction in soft-sediment areas generates an increase in diversity and abundance of infauna and epifauna. Therefore, the establishment of a bivalve culture operation has the ability to shift soft-sediment to hard-bottom, where communities are generally more diverse, have greater biomass and are more productive $[4,11]$. In addition, aquaculture structures such as bags, anchors and ropes can both change the hydrodynamic processes of an area, redirecting water flow, and alter the benthic habitat $[9,27]$.

The effects on the sediments caused by in-bottom clam aquaculture are not as extensively studied as those of oyster and mussel. However, this type of aquaculture deserves a mention, since it involves a number of practices which largely modify the physical environment, clearing intertidal and beach zones of rocks, wood debris and competing species (unwanted species of clam, mussels and barnacles). Also predator species such as snails and starfish are removed and gravel may be added to encourage growth and stabilize the sediments. The culture is then covered with anti-predator netting, which can facilitate the growth of other species otherwise not suitable for coastal areas and can also trap fish. The removal of rocks and debris has the opposite effect of netting on hard-bottom species, since their main natural attachment sites are removed [27].

\section{Effects on native pelagic and benthic species}

Cultured bivalves affect the planktonic and benthic food web by modifying, repacking and increasing the sedimentation rate of fine suspended particles, ultimately altering the availability of food resources to other species. The physical structure of the farm and the fouling that concentrates on bivalves and structures create an attraction for a variety of species. Crabs, other crustaceans, shellfish and demersal fish seem to benefit from culture activities as a result of increased food availability under bivalve suspended culture. In some cases it has been 
shown that the diet of crabs in vicinity of farms switched from algae to mussels as the main component $[2,4,10,15]$. Lobsters (Homarus americanus) appear to be attracted by both the presence of anchor blocks and other structural components of mussel farms, used as refuge, and by the increased food supply constituted by the bivalves themselves and by other species attracted by the farm $[4,28]$. It has been observed that kelp (Laminaria longicrursis) grows abundantly on cultured blue mussel (Mytilus edulis) lines, with new tissue growth both in summer and winter, suggesting that this plant is taking advantage of nutrient release from the bivalves [10]. Bivalve aquaculture can displace or disturb seagrass with culture structures and operations, the farm can also provide an unnatural hard substrate, physical modification of flows and sediments, and shading from light, which affects growth and survival of both macro-algae and seagrass. Moreover, ground-cultured oysters can affect seagrass also by severing the plants with the sharp tips of their shells $[9,15,25]$. Carnivorous fish can be attracted in areas with bivalve farms by an increase in benthic herbivorous fauna; this increase is due to a rise in microphytobenthos, an important food source for the benthic herbivorous fauna, which is in turn caused by increased water clarity from bivalve filtration [8].

In contrast, zooplankton and larval fish that depend on suspended seston as food can compete with bivalve for grazing. Also, both Mercenaria and Mytilus species have the ability to significantly reduce abundance of microzooplankton and mesozooplankton through filtering while oysters may have the capacity to filter and remove larvae of some invertebrate species. However, the importance of this last impact under natural conditions is still unknown $[2,9,10,19]$. Lastly it is significant to note that certain aquaculture practices, such as collection of wild bivalve seed, can have a potential negative impact on native stocks of the cultured species, if collection is done on large proportions of the stocks $[11,15]$.

\section{Introduction of Nonnative Species}

In order to diversify the number of species used in culture operations, introduction of nonnative species has been largely employed in aquaculture. The most renowned examples are the introduction of Pacific oyster (Crassostrea gigas) on the Pacific and Atlantic coast of North America, in Europe, Australia and New Zealand, and the introduction of Mediterranean mussel (Mytilus galloprovincialis) in South Africa [11]. Nonnative bivalve species often exhibit faster growth rates, better resilience to diseases, physiological stress and reproductive output than equivalent native species. Therefore they can become a superior competitor for resources, with the risk of naturalizing and establishing self-sustained populations and dominate endemic species $[9,11]$. They can influence biodiversity, local community composition and the performance of the whole ecosystem and they are more likely to have negative far-field effects compared to cultured endemic bivalve species. However, there appears to be a lack of knowledge on how oysters and other nonnative bivalves impact community and ecosystem level structure and function $[9,11]$.

\section{Diseases and pest introduction}

Numerous diseases have been transferred via movement of infected bivalve stocks. In many cases the fact that the translocated bivalves harbored a disease agent was unknown due to lack of basic knowledge of the disease or inadequate testing and monitoring before the transfer. This has been the case for different oyster diseases. For example, Haplosporidium nelsoni, the causative agent of MSX disease, is a parasite that infects Pacific oysters causing little disease and mortality while it greatly affects eastern oysters. Its transfer via movement of
Pacific oysters has been the cause of a major decline in eastern oyster population in Chesapeake and Delaware Bay [9]. Norcardiosis, caused by the bacterium Nocardia crassostreae, is thought to have originated in Japan and then spread to North America with Pacific oyster transfers [25]. Another renowned and documented case is the introduction of the parasite Bonamia ostreae from the United States to Europe. European flat oysters (Ostrea edulis) transferred from California to France and Spain appear to be the cause of a devastating crash of the flat oyster population in Europe. In this case, however, the presence of the parasite and the high mortality were known and the seeds transferred were erroneously declared disease-free [29].

The intentional introduction of nonnative bivalves has often resulted in the unintentional transfer of nonnative organisms that "hitchhiked" with the introduced species. Nonnative species can hitchhike within the bivalve, on the bivalve, in water or equipment, in the sediment contained in empty shells or even with other hitchhiking organisms [11]. In San Francisco Bay it has been estimated that 20\% of the nonnative species resulted from the shipment of eastern (Crassostrea virginica) and pacific oyster (Crassostrea gigas), many of these species are now important predators and competitors of the resident fauna and flora, as well as pests. In the North Sea it has been estimated that $40 \%$ of nonindigenous species hitchhiked with oyster culture, and 43 exotic macroalgae species were introduced in Southern France. This type of introduction contributed historically, at least as much as international shipping to the spread of exotic species $[4,9,11,25]$. Biofouling organisms have often been introduced with cultured bivalves, especially oysters and mussels. These bivalve species are highly vulnerable to biofouling due to their shells and culture structures thus providing substrate for the settlement of fouling organisms. Pests associated with their transfers include macroalgae (Codium fragile spp. tomentosoides and Undaria pinnatifida), tunicates (Ciona intestinalis and Styela clava) and gastropods (Crepidula fornicata). In some cases, nonnative biofoulers have proliferated, reducing local biodiversity and changing population and community structure in coastal systems. In addition, the bivalves need to be treated with antifouling agents in order to eliminate or reduce the fouling. These treatments are almost universally done over the water. Antifouling agents such as hypochlorite and acetic acid may therefore be added to the environment, and the physical removal of fouling may cause the invasive species to spread or deposit on the bottom $[9,11,25]$.

A particular case of introduction, with repercussion on public health, is the possible transfer of harmful phytoplankton species. It has been proven that the harmful dinoflagellate Alexandrium spp. can be transported in the digestive tract and therefore introduced into new environments by mussel, oyster, clam and scallop, especially at the more robust spore and cysts stages. The viability of the algal cells appears to be significantly reduced at 48 hours post-filtration; therefore, a depuration of 48 hours pre-introduction could minimize the risk of transfer of harmful algae $[4,11,30]$.

It is important to point out that the introduction of nonnative bivalve species for aquaculture purposes is now highly regulated by national and international laws greatly reducing the probability of the introduction of diseases and pests. A code of practice for the introduction of non-native species developed by the International Council for the Exploration of the Sea (ICES) has been adopted by many countries and includes preventive measures such as quarantine, extensive disease testing and hatchery breeding so that only firstgeneration offspring can be released in open water [9,31]. 


\section{Effects on marine mammals and seabirds}

Bivalve aquaculture operations have the potential to impact marine mammals by causing entanglement from farm structures and litter, changes to prey abundance and partially excluding habitats with disturbance. These impacts have only been identified as potential impacts and not yet demonstrated directly for bivalve culture; the exception being a case of entanglement in mussel spat collectors of two Bryde's whales in New Zealand $[9,10,25]$.

Bivalve culture can affect seabirds due to alteration of food sources, displacement of habitat and noise disturbance [25]. When non-native oyster culture is introduced in soft-sediment areas, an increase in abundance of birds can be noticed, and sea ducks appear to be strongly attracted by bivalve aquaculture operations. During mechanical harvesting of clams an increase in the feeding activities of gulls and waders is observed. In these cases aquaculture created a new habitat for associated fauna $[11,27,32]$. However, diving ducks are considered one of the most important predators for bivalve culture, particularly mussels, and deliver considerable damage to farmers [10]. They generally predate preferentially on small mussels, however they have been shown to cause damage to both collectors and commercial mussel ropes [33]. It has been calculated that eider ducks can remove up to 2.6 $\mathrm{Kg}$ of mussels in a day and the total loss for the farm can be anywhere from 30 up to $75 \%$ of the production [10,33]. Many methods have been employed to deter bird predation, including acoustic deterrents, nets, and gunfire [10]. The debate on the most sustainable deterrent is still open. Exclusion nets are currently being studied in order to determine the correct mesh and twine size for different duck species, as shown by Varennes [33].

\section{Evaluation, Control and Prevention of Bivalve Aquaculture Effects}

There are different environmental indicators that have been used to evaluate the interaction between bivalves and the surrounding environment. For effective prevention and mitigation the indicators used need to encompass water quality effects, benthic effects, changes in biodiversity, habitat transformation and carrying capacity [34]. There are indicators that help to understand the movement of water and nutrients in the area of interest such as the ones described by Gibbs [14].

- $\quad$ Clearance efficiency: The ratio between number of days that the water takes to clear an inlet and the number of days it would take for the bivalve to process all the water in the inlet.

- Filtration pressure: The ratio between the total carbon extracted by the bivalve in the water column and total carbon fixed by autotrophs.

- Regulation ratio: The phytoplankton turnover rate over the ratio of the daily volume of water cleared by bivalves to the total volume of water.

- Depletion footprint: It can be measured by fluorometer and conductivity-temperature-depth instruments (CTD) [14].

Moreover, nutrient concentration, dissolved oxygen, bacterial abundance, phytoplankton biomass and size can be measured. Other indicators are used to measure the health of sediments and benthic habitat: redox potential, sediment oxygen concentration, similarity indices, biodiversity metrics and indicator species. Finally, there are socio-economic indicators that evaluate the impact and the interest around bivalve culture. For example, social acceptability of the culture, supply availability and livelihood security for the local communities
$[17,35]$. The information obtained from these indicators can be used independently to give a snapshot of the status of the system and the impact of a farm however they should be used to feed a carrying capacity model or a risk-type matrix as part of a larger management plan [14].

Many efforts have been concentrated on developing complex numerical hydrodynamic carrying capacity models, which take into consideration currents, nutrient, plankton and zooplankton [14]. However, most of the modeling focused on production carrying capacity (optimized level of production of the target species), with few on ecological carrying capacity which considers the whole ecosystem. Given the complexity of carrying capacity models and evaluation, they require expertise in many areas and therefore those models are always the result of collaboration between experts in different fields [36]. Modeling is one of the few tools capable of assessing aquaculture sustainability while also considering the cumulative effects of human activities and resident and invasive species. It is therefore the most complete tool to assess and prevent aquaculture impacts on the environment [35]. A good example of modeling for bivalve aquaculture is the complex Farm Aquaculture Resource Management (FARM) model developed by European researchers, which includes information about production and environmental impact for bivalve farms. It combines hydrodynamics, biogeochemistry, population dynamics and economics into a management tool that became a strong decision-support tool for both growers and regulators. This model has been tested for a variety of systems around Europe, from open coast to estuaries, and on a wide range of cultured bivalves such as Pacific oyster, blue and Mediterranean mussel, and Manila clam. The FARM model also shows the indicators of positive impact provided by bivalve culture in helping to reduce eutrophication in the coastal zones [37]. Also, in Canada a bio-physical ecosystem model assessing the environmental effects, particularly regarding nutrient cycling, of bivalve aquaculture in coastal waters has been developed and validated. This model includes both benthic and pelagic components and the cycling of limiting nutrients [38].

Best management practices (BMP) and performance standards have been used as means of prevention for unacceptable environmental interactions and they are often developed by the industry group itself. Regulatory and certification standards can be developed by the public authority and by the buyers. The goal of these standards is a more sustainable, effective and acceptable aquaculture. However, in order to reduce or limit environmental impacts of bivalve culture, they should be developed and implemented at the ecosystem level $[9,34]$.

All the means of prevention and measurement presented above can be gathered into an ecosystem-based management for bivalve culture. Ecosystem-based management is a comprehensive integrated management of human activities implemented to identify and take action on influences that are critical for the ecosystem. It is a tool to achieve sustainable uses of the ecosystem, maintaining its integrity and encompassing interaction between ecological, social and economic systems [35]. In brief, a bivalve culture ecosystem-based management requires models to assess carrying capacity, policies for hazard identification, risk assessment and management, environmental monitoring programs, impact assessment and communication; it should incorporate the best available scientific knowledge, address phytoplankton interactions, impact on the seabed and interactions between farms, consider cost versus benefits, the potential ecological service provided by cultured bivalves, social issues and economic impact $[17,35]$. 
Table 2 summarizes the main environmental effects and their possible means of evaluation and prevention.

\section{Positive effects of bivalve culture}

The functions of water clarification and biodeposition that characterize filter-feeding bivalves are valuable providers of ecological services to shallow water ecosystems. Bivalves help buffer estuaries and coastal ocean waters against excessive phytoplankton blooms in response to anthropogenic loading of nitrogen, counteracting the symptoms of eutrophication; they also remove inorganic sediments from suspension, counteracting coastal water turbidity. The biodeposition created by mussels and oysters, through the creation of sediment anoxic microzones where denitrifying bacteria are promoted, induce denitrification, which also help to counteract eutrophication by returning nitrogen into the atmosphere as inert nitrogen gas $[3,8,9,39,40]$. Moreover, the enhancement of water clarity due to filtration allows deeper light penetration and therefore can increase the growth of seagrasses that are important nursery habitat for many fish, crustaceans and molluscs; bivalves are therefore capable of enhancing estuarine nursery habitats $[9,40,41]$. These natural functions of bivalves can be employed in aquaculture not only to mitigate the environmental effects of the culture, but also to create added value and services for the surrounding environment.

\section{Restoration}

Natural shellfish populations around the world are in decline due to over-exploitation from fisheries, to decline in estuaries condition and in smaller part to diseases introduction $[42,43]$. As the natural populations decline the important ecosystem services that bivalves provide also drop off and both the water column and the benthic habitat can be affected. It has been therefore suggested that bivalve restoration should be a component of restoring historical baseline conditions and functioning of estuaries. The restoration of oyster in the Chesapeake Bay is the most famous example of bivalve restoration effort $[8,9,41,43$ 45]. Bivalve aquaculture can be considered as an estuarine and coastal ecosystem restoration tool, it could serve to mitigate water quality issues, such as excess chlorophyll and turbidity and even contaminant presence. Although bivalve culture does not provide the same structure created by wild bivalves, culture gears themselves can provide a structural habitat.

It has been suggested that the farmers should receive a compensation for mitigation based on the level of improvement achieved, in addition to selling their product, hence enhancing locally grown seafood production. However, for bivalve aquaculture to work as a restoration tool and give net benefits to the environment, regular removal and responsible disposal of non-native fouling needs to be managed. Moreover, human activities have to be closely controlled to avoid disturbance of any valued species, including birds and marine mammals $[9,44]$.

\section{Re-eutrophication}

In Sweden, blue mussels (Mytilus edulis) have been used for a study on "agro-aqua recycling". Cultured mussels were used to reduce the effects of eutrophication created by excess nutrients discharged in coastal waters from farm land runoff and rural living. They were then harvested and re-used as seafood or in agricultural operations as feedstuff and fertilizer [46]. The use of harvested mussels as a substitution of fishmeal in poultry feed was investigated and was successful $[46,47]$. Moreover, the remainder of mussels and shells were proven to be a valuable land fertilizer, especially interesting for organic farmers who cannot use commercial fertilizers. This model of reeutrophication, nutrient trading and mussel farming resulted therefore in a successful solution for society, environment and industry $[46,48]$. The site has been evaluated until 1.5 years after beginning of operation, and in all cases presented a net removal of nitrogen from the system [49]. Research in this field is currently ongoing in other European countries, such as Denmark and the Netherlands.

\section{Integrated multi-trophic aquaculture (IMTA)}

Mussels and oysters have been involved in studies regarding polyculture systems. Generally, polyculture or integrated multitrophic aquaculture (IMTA) combines fed aquaculture such as finfish or shrimp with extractive aquaculture. Extractive aquaculture utilizes filter-feeding organisms, the bivalves, to remove the organic excess nutrients and seaweeds to remove the inorganic excess nutrients, in order to reduce the environmental impact of fed aquaculture. The bivalves perform as biological filters and environmental cleaners. This type of culture is based on the principle that the solution to pollution is not dilution but extraction and conversion [50,51]. A possible further gain can be the fact that it has been experimentally demonstrated that blue mussels (Mytilus edulis) ingest sea-lice (Lepeophtheirus salmonis) at the copepodid stage and therefore could be a valuable help in controlling sea-lice infestation in farmed salmon [52]. However, Navarrete-Mier [50] showed that excess organic matter produced by a finfish farm in open-water systems was not used by bivalves; the authors conclude therefore that polyculture may not be relevant for diminishing the environmental impact of finfish farms located in areas with high hydrodynamism. It is the opinion of the author that the effect of bivalves in a polyculture system have to be carefully studied in regards to the hydrodynamics of the area during an extended period of time, as the amount of fish waste in the diet of IMTA bivalves varies with season [53]. Critical limitations on the effectiveness of mussels in removing the excess organic nutrients with the current IMTA practices are presented by Cranford [54].

\section{Remediation}

Gifford [55] suggested the use of pearl oyster as bio-remediator in polluted environments. The interest in using pearl oysters, such as Pinctada imbricata and Pinctada margaritifera, for bioremediation is highly attractive since the market value for these species is in the pearl and not in the meat. The authors suggest the possibility to use different pearl oyster species culture in environment polluted by heavy metals, such as lead, copper, zinc and iron; organopollutants, such as PCBs and petroleum hydrocarbons, have been also shown to accumulate in bivalve meat. Finally, pearl oysters can be used as natural filters to clean waters of bacteria, viruses and protozoan from human and animal waste [55]. Pearl oysters have been shown to accumulate significant amounts of pollutants in both meat and shells and therefore they are good candidates for remediation of polluted waters [56]. However, in order to make remediation with bivalve a viable alternative, the disposal of harvested contaminated oysters need to be assessed and addressed. Moreover, tolerance limits of the oyster to certain pollutants need to be investigated, together with their effect on pearl quality [56].

\section{Conclusions}

Bivalve aquaculture success is highly dependent on water quality and a healthy ecosystem. There is no doubt that efforts are made to pursue sustainable culture that protects and maintains the supporting environment by operating within the ecological carrying capacity. 
The author agrees, however, with Hargreaves [34] when he states that sustainability is not an endpoint, but rather a trajectory of constant improvement. In the author opinion, bivalve culture needs to keep evolving, modifying and striving to couple benefits for the farmers with benefits for the environment. "Constant improvement" also encompasses what research can do for bivalve aquaculture. Polyculture, bivalve restoration and use to counteract human eutrophication are directions worth exploring and ecosystem-based management should be developed and implemented in the areas with bivalve operations. In order to do this, more knowledge regarding the direct effects of bivalve culture on the water column and nutrients is needed; in order to have the most accurate picture of culture impact Nizzoli [13] suggested the necessity to monitor sequentially both suspended culture and benthic environment for nutrients. A constant improvement can be reached only with extensive collaboration between researchers in different fields because the interaction between bivalve culture and the environment is complex and encompasses many disciplines such as biology, ecology, oceanography and social sciences.

Ultimately, as stated by McKindsey [4], there is a need to evaluate which of the effects of bivalve aquaculture on the environment are important and which ones are not, and what we should be managing for. Often negative and positive effects of bivalve aquaculture are strictly related and showed together and often the same effect can be considered both negative and positive, depending on the situation. On balance, whether or not bivalve culture has a negative or positive effect depends on the values that are used to weight the different components [4]. And those values are not a privilege of the industry or the scientists, they have to be chosen in collaboration with the whole society.

\section{Acknowledgement}

The author would like to thank Dr. Chris Parrish, Dr. Bill Montevecchi and Dr. Sue Ziegler for the help in developing the topic and for the suggestions to improve this manuscript.

\section{References}

1. Rees J, Pond K, Kay D, Bartram J, Domingo JS (2010) World Health Organization: Safe management of shellfish and harvest waters. IWA Publishing London, United Kingdom.

2. Cranford P, Dowd M, Grant J, Hargrave B, McGladdery S (2003) A scientific review of the potential environmental effects of aquaculture in aquatic systems: Ecosystem level effects of marine bivalve aquaculture. Fisheries and Oceans Canada.

3. Dame RF (1996) Ecology of marine bivalves: an ecosystem approach. CRC Press.

4. McKindsey CW, Archambault P, Callier MD, Olivier F (2011) Influence of suspended and off-bottom mussel culture on the sea bottom and benthic habitats: a review. Can J Zool 89: 622-646.

5. Powell EN, Hofmann EE, Klinck JM, Ray SM (1992) Modeling oyster populations 1. A commentary on filtration rate. Is faster always better? J Shellfish Res 11: 387-389.

6. Rice MA (2008) Environmental effects of shellfish aquaculture in the Northeast. NRAC Publication Fact Sheet 105: 1-6.

7. Newell RIE, Cornwell JC, Owens MS (2002) Influence of simulated bivalve biodeposition and microphytobenthos on sediment nitrogen dynamics: a laboratory study. Limnol Oceanogr 47: 1367-1379.

8. Newell RIE (2004) Ecosystem influence of natural and cultivated populations of suspension-feeding bivalve molluscs: a review. J Shellfish Res 23: 51-61.

9. National Research Council (2010) Ecosystem concepts for sustainable bivalve mariculture. The National Academy Press, Washington, DC

10. McKindsey CW, Anderson MR, Barnes P, Courtenay S, Landry T, et al. (2006) Effects of shellfish aquaculture on fish habitat. Canadian Science Advisory Secretariat, Fisheries and Oceans Canada.
11. McKindsey CW, Landry T, O'Beirn FX, Davies IM (2007) Bivalve aquaculture and exotic species: a review of ecological consideration and management issues. J Shellfish Res 26: 281-294.

12. Dumbauld BR, Ruesink JL, Rumrill SS (2009) The ecological role of bivalve shellfish aquaculture in the estuarine environment: a review with application to oyster and clam culture in West Coast (USA) estuaries. Aquaculture 290 196-223.

13. Nizzoli D, Welsh DT, Fano EA, Viaroli $P$ (2006) Impact of clam and musse farming on benthic metabolism and nitrogen cycling, with emphasis on nitrate reduction pathways. Mar Ecol Prog Ser 315: 151-165.

14. Gibbs MT (2007) Sustainability performance indicators for suspended bivalve aquaculture activities. Ecol Indic 7: 94-107.

15. Gavine FM, Mc Kinnon LJ (2002) Environmental monitoring of marine aquaculture in Victorian coastal waters: a review of appropriate methods. Marine and Freshwater Institute Victoria.

16. Kaspar HF, Gillespie PA, Boyer IC, MacKenzie AL (1985) Effects of musse aquaculture on the nitrogen cycle and benthic communities in Kenepuru Sound Marlborough Sounds New Zealand. Mar Biol 85: 127-136.

17. Cranford PJ, Anderson R, Archambault P, Balch T, Bates SS, et al. (2006) Indicators and thresholds for use in assessing shellfish aquaculture impacts on fish habitat. Canadian Science Advisory Secretariat Fisheries and Oceans Canada.

18. Anderson MR, Cranford PJ, McKindsey CW, Strain P, Hargrave BT, et al. (2006) Cumulative and far-field fish habitat effects. Canadian Science Advisory Secretariat, Fisheries and Oceans Canada.

19. Fabi G, Manoukian S, Spagnolo A (2009) Impact of an open-sea suspended mussel culture on macrobenthic community (Western Adriatic Sea). Aquaculture 289: 54-63.

20. Chamberlain J, Fernandes TF, Read P, Nickell TD, Davies IM (2001) Impacts of biodeposits from suspended mussel (Mytilus edulis L.) culture on the surrounding surficial sediments. ICES J Mar Sci 58: 411-416.

21. da Costa KG, Nalesso RC (2006) Effects of mussel farming on macrobenthic community structure in Southeastern Brazil. Aquaculture 258: 655-663.

22. Crawford CM, Macleod CKA, Mitchell IM (2003) Effects of shellfish farming on the benthic environment. Aquaculture 224: 117-140.

23. Callier MD, Richard M, McKindsey CW, Archambault P, Desrosiers G (2009) Responses of benthic macrofauna and biogeochemical fluxes to various levels of mussel biodeposition: an in situ "benthocosm" experiment. Mar Pollut Bull 58: $1544-1553$.

24. Hartstein ND, Rowden AA (2004) Effect of biodeposits from mussel culture on macroinvertebrate assemblages at sites of different hydrodynamic regime. Mar Environ Res 57: 339-357

25. Forrest BM, Keeley NB, Hopkins GA, Webb SC, Clement DM (2009) Bivalve aquaculture in estuaries: review and synthesis of oyster cultivation effects. Aquaculture 298: 1-15

26. Fréchette M (2012) Self-thinning, biodeposits production, and organic matter input to the bottom in mussel suspension culture. J Sea Res 67: 10-20.

27. McKindsey CW (2010) Aquaculture-related physical alterations of habita structures as ecosystem stressors. Canadian Science Advisory Secretariat. Fisheries and Oceans Canada.

28. D'Amours O, Archambault P, McKindsey CW, Johnson LE (2008) Local enhancement of epibenthic macrofauna by aquaculture activities. Mar Ecol Prog Ser 371: 73-84.

29. Elston RA, Ford SE (2011) Shellfish Aquaculture and the Environment: Shellfish diseases and health management. United Kingdom.

30. Hégaret H, Shumway SE, Wikfors GH, Pate S, Burkholder JM (2008) Potentia transport of harmful algae via relocation of bivalve molluscs. Mar Ecol Prog Ser 361: 169-179.

31. Hedgecock D (2011) Shellfish Aquaculture and the Environment: Genetics of shellfish on a human-dominated planet. United Kingdom.

32. Žydelis R, Esler D, Kirk M, Boyd WS (2009) Effects of off-bottom shellfish aquaculture on winter habitat use by molluscivorous sea ducks. Aquat Conserv 19: 34-42. 
Citation: Gallardi D (2014) Effects of Bivalve Aquaculture on the Environment and Their Possible Mitigation: A Review. Fish Aquac J 5: 105. doi: 10.4172/2150-3508.1000105

33. Varennes É, Hanssen SA, Bonardelli J, Guillemette M (2013) Sea duck predation in mussel farms: the best nets for excluding common eiders safely and efficiently. Aquacult Environ Interact 4: 31-39.

34. Hargreaves JA (2011) Shellfish Aquaculture and the Environment: Molluscan shellfish aquaculture and best management practices. United Kingdom.

35. Cranford PJ, Kamermans P, Krause G, Mazurié J, Buck BH, et al. (2012) An ecosystem-based approach and management framework for the integrated evaluation of bivalve aquaculture impacts. Aquacult Environ Interact 2: 193213.

36. McKindsey CW, Thetmeyer H, Landry T, Silvert W (2006) Review of recent carrying capacity models for bivalve culture and recommendations for research and management. Aquaculture 261: 451-462.

37. Ferreira JG, Sequeira A, Hawkins AJS, Newton A, Nickell TD, et al. (2009) Analysis of coastal and offshore aquaculture: application of the FARM model to multiple systems and shellfish species. Aquaculture 289: 32-41.

38. Dowd M (2005) A bio-physical coastal ecosystem model for assessing environmental effects of marine bivalve aquaculture. Ecol Model 183: 323-346.

39. Officer CB, Smayda TJ, Mann R (1982) Benthic filter feeding: a natural eutrophication control. Mar Ecol Prog Ser 9: 203-210.

40. Newell RIE, Koch EW (2004) Modeling seagrass density and distribution in response to changes in turbidity stemming from bivalve filtration and seagrass sediment stabilization. Estuaries 27: 793-806.

41. Cerco CF, Noel MR (2007) Can oyster restoration reverse cultural eutrophication in Chesapeake Bay? Estuar Coast 30: 331-343.

42. Brumbaugh RD, Beck MW, Coen LD, Craig L, Hicks P (2006) A Practitioners' Guide to the Design and Monitoring of Shellfish Restoration Projects: An Ecosystem Services Approach. The Nature Conservancy, Arlington, VA.

43. Fulford RS, Breitburg DL, Newell RIE, Kemp WM, Luckenbach M (2007) Effects of oyster population restoration strategies on phytoplankton biomass in Chesapeake Bay: a flexible modeling approach. Mar Ecol Prog Ser 336: 43-61.

44. Burkholder JM, Shumway SE (2011) Shellfish Aquaculture and the Environment: Bivalve shellfish aquaculture and eutrophication. United Kingdom.

45. Ulanowicz RE, Tuttle JH (1992) The trophic consequences of oyster stock rehabilitation in Chesapeake Bay. Estuaries 15: 298-306.

Citation: Gallardi D (2014) Effects of Bivalve Aquaculture on the Environment and Their Possible Mitigation: A Review. Fish Aquac J 5: 105. doi: 10.4172/2150 3508.1000105
46. Lindahl O (2011) Shellfish Aquaculture and the Environment: Mussel farming as a tool for re-eutrophication of coastal waters: experiences from Sweden. United Kingdom.

47. Jönsson L, Elwinger K (2009) Mussel meal as a replacement for fish meal in feeds for organic poultry- a pilot short term study. Acta Agr Scand A-An 59: $22-27$

48. Edebo L, Haamer J, Lindahl O, Loo LO, Piriz L (2000) Recycling of macronutrients from sea to land using mussel cultivation. Int $\mathrm{J}$ Environ Pollut 13: $190-207$.

49. Carlsson MS, Engström P, Lindahl O, Ljungqvist L, Petersen JK, et al. (2012) Effects of mussel farms on the benthic nitrogen cycle on the Swedish west coast. Aquacult Environ Interact 2:177-191.

50. Navarrete-Mier F, Sanz-Lázaro C, Marín A (2010) Does bivalve molluscs polyculture reduce marine fin fish farming environmental impact? Aquaculture 306: 101-107.

51. Chopin T, Cooper JA, Reid G, Cross S, Moore C (2012) Open-water integrated multi-trophic aquaculture: environmental biomitigation and economic diversification of fed aquaculture by extractive aquaculture. Rev Aquaculture 4: 209-220.

52. Molloy SD, Pietrak MR, Bouchard DA, Bricknell I (2011) Ingestion of Lepeophtheirus salmonis by the blue mussel Mytilus edulis. Aquaculture 311 : 61-64.

53. Mazzola A, Sarà G (2001) The effect of fish farming organic waste on food availability for bivalve molluscs (Gaeta Gulf, Central Tyrrhenian, MED): stable carbon isotope analysis. Aquaculture 192: 361-379.

54. Cranford PJ, Reid GK, Robinson SMC (2013) Open water integrated multitrophic aquaculture: constraints on the effectiveness of mussels as an organic extractive component. Aquacult Environ Interact 4: 163-173.

55. Gifford S, Dunstan RH, O'Connor W, Roberts T, Toia R (2004) Pearl aquacultureprofitable environmental remediation? Sci Total Environ 319: 27-37.

56. Gifford S, Dunstan H, O'Connor W, Macfarlane GR (2005) Quantification of in situ nutrient and heavy metal remediation by a small pearl oyster (Pinctada imbricata) farm at Port Stephens, Australia. Mar Pollut Bull 50: 417-422.

Submit your next manuscript and get advantages of OMICS Group submissions

Unique features:

- User friendly/feasible website-translation of your paper to 50 world's leading languages

- Audio Version of published paper

Digital articles to share and explore

Special features:

300 Open Access Journal

25,000 editorial team

21 days rapid review proce

Quality and quick editorial, review and publication processing

Indexing at PubMed (partial), Scopus, EBSCO, Index Copernicus and Google Scholar etc

Sharing Option: Social Networking Enabled

- Authors, Reviewers and Editors rewarded with online Scientific Credits

Better discount for your subsequent articles

Submit your manuscript at: http://www.omicsonline.org/submission 